\title{
THE EFFECT OF URBAN GREEN SPACES ON HOUSE PRICES IN WARSAW
}

\author{
Radoslaw TROJANEK ${ }^{1, *}$, Michal GLUSZAK ${ }^{2}$, Justyna TANAS ${ }^{3}$ \\ ${ }^{1}$ Department of Microeconomics, Poznan University of Economics and Business, Al. Niepodleglosci 10, \\ 61-875 Poznan, Poland \\ ${ }^{2}$ Department of Real Estate and Investment Economics, Cracow University of Economics, \\ ul. Rakowicka 27 bld. B, 31-510 Krakow, Poland \\ ${ }^{3}$ Department of Investment and Real Estate, University of Gdansk, ul. Bazynskiego 8, 80-309 Gdansk, Poland
}

Received 17 July 2017; accepted 18 November 2017

\begin{abstract}
In the paper, we analysed the impact of proximity to urban green areas on apartment prices in Warsaw. The dataset contained in 43075 geo-coded apartment transactions for the years 2010 to 2015. In this research, the hedonic method was used in Ordinary Least Squares (OLS), Weighted Least Squares (WLS) and Median Quantile Regression (Median QR) models. We found substantial evidence that proximity to an urban green area is positively linked with apartment prices. On an average presence of a green area within 100 meters from an apartment increases the price of a dwelling by $2,8 \%$ to $3,1 \%$. The effect of park/forest proximity on house prices is more significant for newer apartments than those built before 1989. We found that proximity to a park or a forest is particularly important (and has a higher implicit price as a result) in the case of buildings constructed after 1989. The impact of an urban green was particularly high in the case of a posttransformation housing estate. Close vicinity (less than $100 \mathrm{~m}$ distance) to an urban green increased the sales prices of apartments in new residential buildings by $8,0-8,6 \%$, depending on a model.
\end{abstract}

Keywords: hedonic methods, parks, urban green, property prices.

\section{Introduction}

The market value of a property depends mainly on its physical characteristics, out of which the most important is location. The location choices depend mostly on individual preferences but generally can be related to the distance from work, schools, and hospitals, an accessibility of public transport, positive or negative neighbourhood effects both about built and natural environment. Among, various factors affecting housing choices, and thus house prices, environmental attributes rank very high in the hierarchy of importance (Źróbek, M. Trojanek, ŹróbekSokolnik, \& R. Trojanek, 2015; Gluszak \& Marona, 2017).

Green spaces not only provide a pleasant and natural environment but also improve the quality of life in urban areas and undertake essential environmental functions (B. Zhang, Xie, C. Zhang, \& J. Zhang, 2012; Streimikiene, 2014). A considerable range of benefits provided by urban green areas has been studied and reported in the literature. The list includes, but is not limited to (Konijnendijk, Annerstedt, Maruthaveeran, \& Nielsen, 2013): human health and wellbeing, social cohesion, tourism, biodiversity, air qual- ity and carbon sequestration, water management and the role of parks in the cooling of urban areas. Moreover, green spaces have a significant economic effect, most notably an impact on neighbouring property values. The latter effect was reported in a great number of research papers (for example Espey \& Owusu-Edusei, 2001; Jim \& Chen, 2010).

The topic of urban green in CEE (Central and Eastern Europe) cities has been neglected in the discussion on the post-1989 transformation of the major metropolitan areas. Like many cities in the region, Warsaw experienced discontinuity of urban development (Staniszkis, 2012), and as a metropolitan area entity consists of two different systems. First of them is a heritage of a socialist period, and it is key characteristics are relatively low housing quality, but low development densities (building coverage ratios), greenness, and well-planned accessible public infrastructure. The second urban system is an effect of spontaneous, chaotic and dynamic development (Kusiak, 2012), that was not adequately regulated, due to malfunctions in urban planning. The higher quality of housing often comes at a price of high development density, lack of urban green

*Corresponding author. E-mail: r.trojanek@ue.poznan.pl 
areas, and lack of sufficient public infrastructure. From this perspective, Warsaw is, in fact, two cities - planned and spontaneous, each representing contradictory forces shaping its urban form. The problem with the latter is that unregulated new residential development has hampered the existing public green spaces in Warsaw and resulted in urban sprawl (Mantey, 2017). The paper aims to address the implicit value of urban green areas, in case of both for pre and post-1989 housing stock.

In the paper, we analyse the effect of proximity to urban green areas on housing prices in Warsaw. The remaining part of this paper is structured as follows. Section 1 addresses the existing empirical research impact of parks, recreation areas and urban green on real estate prices. Section 2 discusses on data issues and methods used in the study. Section 3 comments on the results and confronts them with previous findings in the relevant literature. The last section assesses the results and suggests directions for future research.

\section{Literature review}

The urbanisation process, which is accompanied by the growing population in cities, is absorbing green areas in urban and suburban areas (Tanaś \& Trojanek, 2014; Źróbek-Różańska \& Zadworny, 2016). This situation requires efforts that aim at maintaining or restoring green areas because this space is essential for the quality of life in cities (Zhou \& Parves Rana, 2012). Green belts fulfil some functions and generate various benefits for urban dwellers (Robinette, 1972; Grey \& Deneke, 1978; Laurie, 1979). Studies on the positive influence of green areas in cities have been conducted in many countries for years. An overview of the existing body of literature helps us single out the following categories of general benefits of urban green areas (Sadeghian \& Vardanyan, 2013):

- environmental, including ecological benefits, pollution reduction, cooling urban areas, ensuring biodiversity and wildlife conservation;

- economic, including saving energy, influence on water balance, increasing the tourist attractiveness of urban areas, an increase in the value of properties;

- social and psychological, as a place of entertainment and recreation, improvement of health and physical and mental state, strengthening social bonds, crime reduction;

- planning and designing, including the perception of green areas, aesthetic values, planning and designing green areas.

Some of the benefits listed above can have market effects and can be captured using hedonic models. More in line with hedonic pricing framework Sarkar et al. (2015) identify five reasons why proximity to urban green can increase residential satisfaction, and thus affect housing choices and house prices: (i) creating recreation possibilities, (2) strengthening community bonds and increasing social capital, (3) health and stress relief, (4) natural filtration against pollution, (5) protection of urban heat islands.
The significant impact of urban green areas on real estate prices is confirmed by numerous studies carried out over the last few decades. A valuable overview of literature concerning this issue was provided by Crompton (Crompton, 2001). Among 30 studies he analysed, there were only five not supporting the proximity principle, i.e. that having a park nearby raises property prices. One of the first studies related to this problem was conducted in the USA in 1960. Due to the applied methodology, however, the results were not consistent. The research carried out by Knetsch (Knetsch, 1964) showed that benefits of an attractive location, such as on the shoreline, may contribute to the growth in the value of the property. In another study, no and uniform influence of the neighbourhood of recreational areas on real estate prices was observed (Hendon, 1971).

By the analysis of literature, the studies conducted so far may be arranged by taking into account first of all the applied research method, and then the type and size of green areas and the kind of property.

On account of the applied research method, most studies have been carried out with the application of revealed preference methods and stated preference methods, both based on the theory of consumer choice. The former group, represented mostly by hedonic regression studies, investigates economic value of green spaces. The embedded assumption is that the property is the function of various structural, location and neighbourhood characteristics (urban green being one of them), thus observed prices could be decomposed into implicit prices of attributes. With rare exceptions (Biao, Gaodi, Bin, \& Canqiang, 2012) this branch of empirical research relies on individual property information (sales, rentals, offers). The latter approach, applying quasi-experimental, qualitative or survey methods, analyses explicitly preferences, consequences and values households (buyers or renters) attached to various attributes, and links between them (McConnell \& Walls, 2005).

In a number of studies, real estate prices have been analysed depending on the kind of green areas, e.g. parks (Weigher \& Zerbst, 1973; Espey \& Owusu-Edusei, 2001), forests (Tyrväinen \& Miettinen, 2000), greenbelts (Lee \& Linneman, 1998; Herath, Choumert, \& Maier, 2015), golf courses (Do \& Grudnitski, 1995), or wetlands (Doss \& Taff, 1996; Mahan, Polasky, \& Adams, 2000; Earnhart, 2001). Research has shown that the degree of influence depends on the type of green areas that property borders and on the distance from these areas (Bolitzer \& Netusil, 2000; Lutzenhiser \& Netusil, 2001). It has also been pointed out that the degree to which a park influences its neighbourhood is dependent on its attractiveness, extra facilities and landscape (Millward \& Sabir, 2011).

Studies also differ regarding the type of properties for which the influence of green areas on prices was examined. Some studies deal with the impact of green areas on the prices of flats (Morancho, 2003; Hoshino \& Kuriyama, 2010; Jim \& Chen, 2010; Kolbe \& Wüstemann, 2014). The influence of the neighbourhood of parks on land properties was in turn examined by, among others, 
Hendon (1971) and Zygmunt and Gluszak (2015). Other studies show the impact of green areas on single-family house prices (Anderson \& Cordell, 1998; Anderson, 2000; Dombrow, Rodriguez, \& Sirmans, 2000; Luttik, 2000; Des Rosiers, Thériault, Kestens, \& Villeneuve, 2002; Conway, Li, Wolch, Kahle, \& Jerrett, 2010; Bark, Osgood, Colby, \& Halper, 2011; Kim, Li, Newman, Kil, \& Park, 2016). In the case of single-family houses, when the plot area is large (a garden may be treated as private leisure space), the influence of parks on the price is small. It may also be assumed that the vicinity of a park is more important for multifamily housing than for single-family housing.
Most studies have been conducted in the USA, Western Europe and Asia. In recent years, a few studies on the issues discussed above have also been carried out in Poland (Zygmunt \& Gluszak, 2015; Czembrowski \& Kronenberg, 2016; Trojanek, 2016; Trojanek, Tanas, Raslanas, \& Banaitis, 2017). Table 1 presents the description and results of recent studies (published in 2010 and later) of the influence of urban green areas on real estate prices.

Some general conclusions can be drawn from the empirical research on urban green areas. There is a consensus on the positive influence of the vicinity of parks on the market price of urban residential real estate. It was con-

Table 1. Recent research on Urban Green Areas (UGA) and property prices (source: own research)

\begin{tabular}{|c|c|c|c|c|c|c|}
\hline Lp. & $\begin{array}{l}\text { Place of } \\
\text { Research }\end{array}$ & $\begin{array}{l}\text { Authors of } \\
\text { research }\end{array}$ & $\begin{array}{l}\text { Type of } \\
\text { property }\end{array}$ & Number of samples & $\begin{array}{l}\text { Time of } \\
\text { research }\end{array}$ & Findings \\
\hline 1. & $\begin{array}{l}\text { Vermont } \\
\text { corridor, Los } \\
\text { Angeles (USA) }\end{array}$ & $\begin{array}{l}\text { Conway et al. } \\
(2010)\end{array}$ & $\begin{array}{l}\text { Single-family } \\
\text { residences }\end{array}$ & 260 transactions & $1999-2000$ & $\begin{array}{l}\text { Significant positive effect of UGA on } \\
\text { property prices }\end{array}$ \\
\hline 2. & $\begin{array}{l}\text { Setagaya Ward, } \\
\text { Tokyo (Japan) }\end{array}$ & $\begin{array}{l}\text { Hoshino and } \\
\text { Kuriyama } \\
(2010)\end{array}$ & $\begin{array}{l}\text { Single room } \\
\text { dwellings }\end{array}$ & $\begin{array}{l}2370 \text { apartments } \\
\text { for rent }\end{array}$ & 2007 & $\begin{array}{l}\text { The effect depends on park size. } \\
\text { Significant positive effect of UGA on } \\
\text { apartment rents for medium-size parks. }\end{array}$ \\
\hline 3. & $\begin{array}{l}\text { Hong Kong } \\
\text { (China) }\end{array}$ & $\begin{array}{l}\text { Jim and Chen } \\
(2010)\end{array}$ & Apartments & 1471 transactions & $2005-2006$ & $\begin{array}{l}\text { Significant positive effect of UGA } \\
\text { on property prices (mostly due to } \\
\text { recreational availability, but also to view). }\end{array}$ \\
\hline 4. & $\begin{array}{l}\text { Tucson, } \\
\text { Arizona (USA) }\end{array}$ & $\begin{array}{l}\text { Bark et al. } \\
(2011)\end{array}$ & $\begin{array}{l}\text { Single family } \\
\text { residence }\end{array}$ & 6676 transactions & $1998-2003$ & $\begin{array}{l}\text { Significant positive effect of UGA on } \\
\text { property price }\end{array}$ \\
\hline 5. & Beijing (China) & $\begin{array}{l}\text { Biao et al. } \\
(2012)\end{array}$ & $\begin{array}{l}\text { Residential } \\
\text { properties }\end{array}$ & $\begin{array}{l}\text { The average house } \\
\text { prices in } 76 \text { resi- } \\
\text { dential areas and } \\
14 \text { parks in Beijing }\end{array}$ & 2009 & $\begin{array}{l}\text { Significant positive effect of UGA on } \\
\text { property price, but the results vary }\end{array}$ \\
\hline 6. & $\begin{array}{l}\text { Aalborg } \\
\text { (Denmark) }\end{array}$ & $\begin{array}{l}\text { Panduro and } \\
\text { Veie (2013) }\end{array}$ & $\begin{array}{l}\text { Houses, } \\
\text { apartments, }\end{array}$ & 12928 transactions & $2000-2007$ & $\begin{array}{l}\text { Mixed-effect of UGA on property } \\
\text { prices, results depend on UGA type and } \\
\text { differ for various types of properties }\end{array}$ \\
\hline 7. & Belfast (UK) & $\begin{array}{l}\text { McCord et al. } \\
(2014)\end{array}$ & $\begin{array}{l}\text { Detached, } \\
\text { semi-de- } \\
\text { tached, terrace } \\
\text { and apartment }\end{array}$ & 3854 transactions & 2011 & $\begin{array}{l}\text { Significant positive effect of UGA on } \\
\text { property prices, the results depend on } \\
\text { property type, the strongest impact was } \\
\text { observed for apartments. }\end{array}$ \\
\hline 8. & $\begin{array}{l}\text { Cologne } \\
\text { (Germany) }\end{array}$ & $\begin{array}{l}\text { Kolbe and } \\
\text { Wüstemann } \\
(2014)\end{array}$ & Apartments & 85046 transactions & 1995-2012 & $\begin{array}{l}\text { Significant positive effect of UGA on } \\
\text { property prices }\end{array}$ \\
\hline 9. & $\begin{array}{l}\text { Cracow } \\
\text { (Poland) }\end{array}$ & $\begin{array}{l}\text { Zygmunt and } \\
\text { Gluszak (2015) }\end{array}$ & $\begin{array}{l}\text { Undeveloped } \\
\text { land }\end{array}$ & 355 transactions & $2002-2011$ & $\begin{array}{l}\text { Significant positive effect of UGA on } \\
\text { property prices }\end{array}$ \\
\hline 10. & $\begin{array}{l}\text { Vienna } \\
\text { (Austria) }\end{array}$ & $\begin{array}{l}\text { Herath et al. } \\
(2015)\end{array}$ & Apartments & $\begin{array}{l}1651 \text { apartments } \\
\text { for sale }\end{array}$ & $2009-2010$ & $\begin{array}{l}\text { Significant positive effect of UGA on } \\
\text { property prices }\end{array}$ \\
\hline 11. & Lodz (Poland) & $\begin{array}{l}\text { Czembrowski } \\
\text { and Kronenberg } \\
(2016)\end{array}$ & Apartments & 9346 transactions & $2011-2013$ & $\begin{array}{l}\text { Significant positive effect of UGA on } \\
\text { property prices, the results depend on } \\
\text { UGA type }\end{array}$ \\
\hline 12. & $\begin{array}{l}\text { Poznan } \\
\text { (Poland) }\end{array}$ & Trojanek (2016) & Apartments & 1438 transactions & $2013-2014$ & $\begin{array}{l}\text { Significant positive effect of UGA on } \\
\text { property prices }\end{array}$ \\
\hline 13. & $\begin{array}{l}\text { Austin, TX } \\
\text { (USA) }\end{array}$ & $\begin{array}{l}\text { Kim et al. } \\
(2016)\end{array}$ & $\begin{array}{l}\text { Single-family } \\
\text { houses }\end{array}$ & 11326 transactions & 2010-2012 & $\begin{array}{l}\text { Significant positive effect of UGA on prop- } \\
\text { erty prices, the results depend on UGA } \\
\text { size and structure (the most influential } \\
\text { impact for large, non-fragmented UGA }\end{array}$ \\
\hline 14. & $\begin{array}{l}\text { Helsinki } \\
\text { (Finland) }\end{array}$ & Votsis (2017) & Apartments & 44300 transactions & $2000-2011$ & $\begin{array}{l}\text { Significant positive effect of UGA on } \\
\text { property prices, the results depend on } \\
\text { UGA type and distance to the city centr }\end{array}$ \\
\hline 15. & $\begin{array}{l}\text { Leipzig } \\
\text { (Germany) }\end{array}$ & $\begin{array}{l}\text { Liebelt, Bartke, } \\
\text { and Schwarz } \\
(2018)\end{array}$ & $\begin{array}{l}\text { Apartments } \\
\text { for rent, sale; } \\
\text { houses for } \\
\text { rent and sale }\end{array}$ & $\begin{array}{l}290559 \\
\text { asking prices/rents }\end{array}$ & $2007-2013$ & $\begin{array}{l}\text { Significant positive but fairly small } \\
\text { impact on housing prices, The results } \\
\text { depend on the type of housing. }\end{array}$ \\
\hline
\end{tabular}


firmed in different cities all over the world, in different economic and cultural conditions. The positive proximity effect is not linear and tends to disappear with the distance. Moreover, although the literature is consistent on premium price attached to the presence of urban green areas, the effect can vary depending on its type, accessibility, diversity, and extra recreation facilities (Crompton, 2005; Panduro \& Veie, 2013; McCord et al., 2014). There is also evidence that scarcity of urban green in the city and density of development can affect the urban green premium (Herath et al., 2015; Votsis, 2017). Nonetheless, the literature reports several cases when proximity to a park causes negative externalities and decreases property values: fire risk exposure or poor management, and vulnerability to crime (Troy, J. M. Grove, \& J. M. Grove, 2008). To conclude, although the presence of an urban green seems to be an important factor in housing decisions there are few empirical papers on the impact of urban green areas on property prices in major cities in Central and Eastern Europe. Despite recent efforts to explore the influence of (1) development density and (2) substitution effects between public and private space on urban green premiums some unanswered questions remain. In this paper, we ask whether the implicit price for the proximity to the urban green area is similar in case of pre- and post-transition dwellings.

\section{Methods and data}

\subsection{Study area}

Warsaw is the capital of Poland. The housing market in Warsaw is undoubtedly the biggest market in Poland. One reason may be the size of the conurbation, which - being the capital of Poland - is the city of the largest population in Poland. Moreover, not only is Warsaw the heart of political activity, but it is also the centre of economic, cultural and scientific life. Forests in Warsaw occupy an area of about $7258 \mathrm{ha}$, which accounts for nearly $14 \%$ of the city's surface. It makes Warsaw one of the few European capitals with such a large share of forest complexes in the total area of the city. In the existing administrative system, the City of Warsaw is in possession of 76 parks with a total area of about 715 ha.

Szulczewska and Kaliszuk (2003) argue that urban planning in Warsaw faces a dilemma, as planners must choose between the idea of a compact city (thus limiting the urban green space within) or green city (thus allowing further urban sprawl).

\subsection{Hypothesis development and variables}

Our study seeks to explore how the proximity to park/forest is capitalized in property prices. The theoretical underpinning for the research roots is based on utility theory. There are several benefits of urban green areas which can result in higher residential satisfaction. Most of them were discussed and studied extensively in the relevant literature.

On an efficient market higher residential satisfaction (thus higher housing utility) will result in higher rent (and higher market value) of a housing unit. As a consequence, the proximity to park or forest should, in theory, result in higher property prices. The question arises, however, whether the effect is uniform for all: (1) cities, (2) types of housing units. In the former case, proximity to a park should be particularly attractive in case of cities, with an insufficient share of green areas. In latter case, the

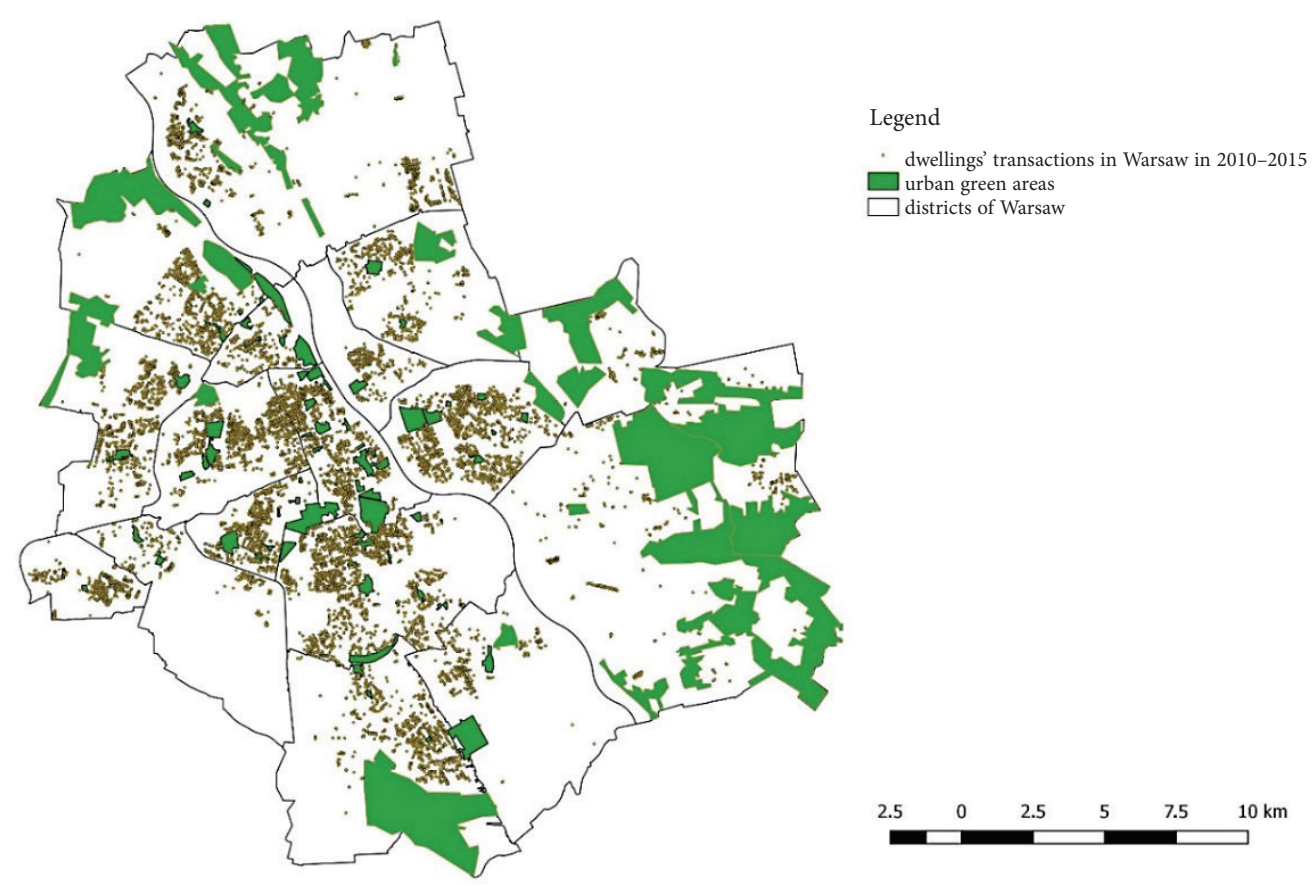

Figure 1. Urban green area and dwelling transactions in Warsaw in years 2010-2015 (source: study based on own research and Board of Geodesy and Municipal Cadastre in Warsaw) 
economic reasoning suggests that implicit value of public green areas is linked with availability of substitutes. The example of substitutes include, but are not limited to:

- private gardens in case of single-family houses;

- an enclave of gardens or recreation grounds in case of gated communities;

- promenades, waterfronts, and small green areas between buildings.

While alternatives listed above do not substitute perfectly for a large park, their presence can lower general dissatisfaction resulting from the lack of urban green in the vicinity. One can suspect that although access to public green areas is positive, it will be particularly attractive for residents of densely developed housing estates lacking green areas, and relatively less attractive for estates with an abundance of green areas between buildings. The same logic applies to a willingness to pay for proximity to urban green. Put it differently; we hypothesise that the implicit price of proximity to urban green will differ about the type of housing estate. We suspect that marginal willingness to pay for urban green will be higher in case of post-transformation dwellings.

Warsaw makes a great study area to examine the hypothesis like this. For one, the city has an intriguing urban landscape, resulting from dramatic and turbulent historical events in the 20th century. The residential stock in Warsaw reflects both catastrophic events (the destruction of the majority of buildings in the city after Warsaw Uprising, and subsequent redevelopment of Old Town) and economic system transformation (large scale modernist housing projects typical to a socialist period from 1945 to 1989 , followed by a period of spontaneous and chaotic development and urban sprawl after transformation in 1990s and 2000s). The diversity of housing stock allowed us to check how proximity to urban green is capitalized in prices of different types of residential projects.

In the mid-1990s, around $44 \%$ of the area of Warsaw was built-up. The average density of the built-up area 7 is 67 peoples per hectare or about 150 square meters of land per person. Bertaud (A. Bertaud \& M. A. Bertaud, 2000) claims that development density is comparable with other metropolitan areas in Europe (higher than London and Berlin, and lower than in Moscow). Interestingly, the relation between density and distance from the city centre resembles a negatively sloped exponential curve. This particular density pattern is typical for cities in mature market economies, but in case of Warsaw, it is mainly the product of post-II WW socialist planning process (A. Bertaud \& M. A. Bertaud, 2000). In the first decade of Warsaw experienced a dynamic period of suburbanization, that resulted in uncontrolled urban sprawl (Degórska, 2012). The process of erosion of clear urban boundaries was observed in other CEE cities (Nedović-Budić \& Tsenkova, 2006; Stanilov \& Sýkora, 2014).

Housing stock evolution in Warsaw (Figure 2) resembles a situation in other major cities in Poland - from mass public housing projects that characterized a socialist period (with medium development densities, and relatively accessible green areas around buildings) to small, disconnected private housing projects (with profit-driven high densities and relative lack of green space around). A study conducted in Wroclaw revealed that about $45 \%$ developments completed during a transformation period in the 1990s and 2000s had considerably high development density (building coverage ratios around of $0.25-$ 0.35 ) - a development density considerably higher than
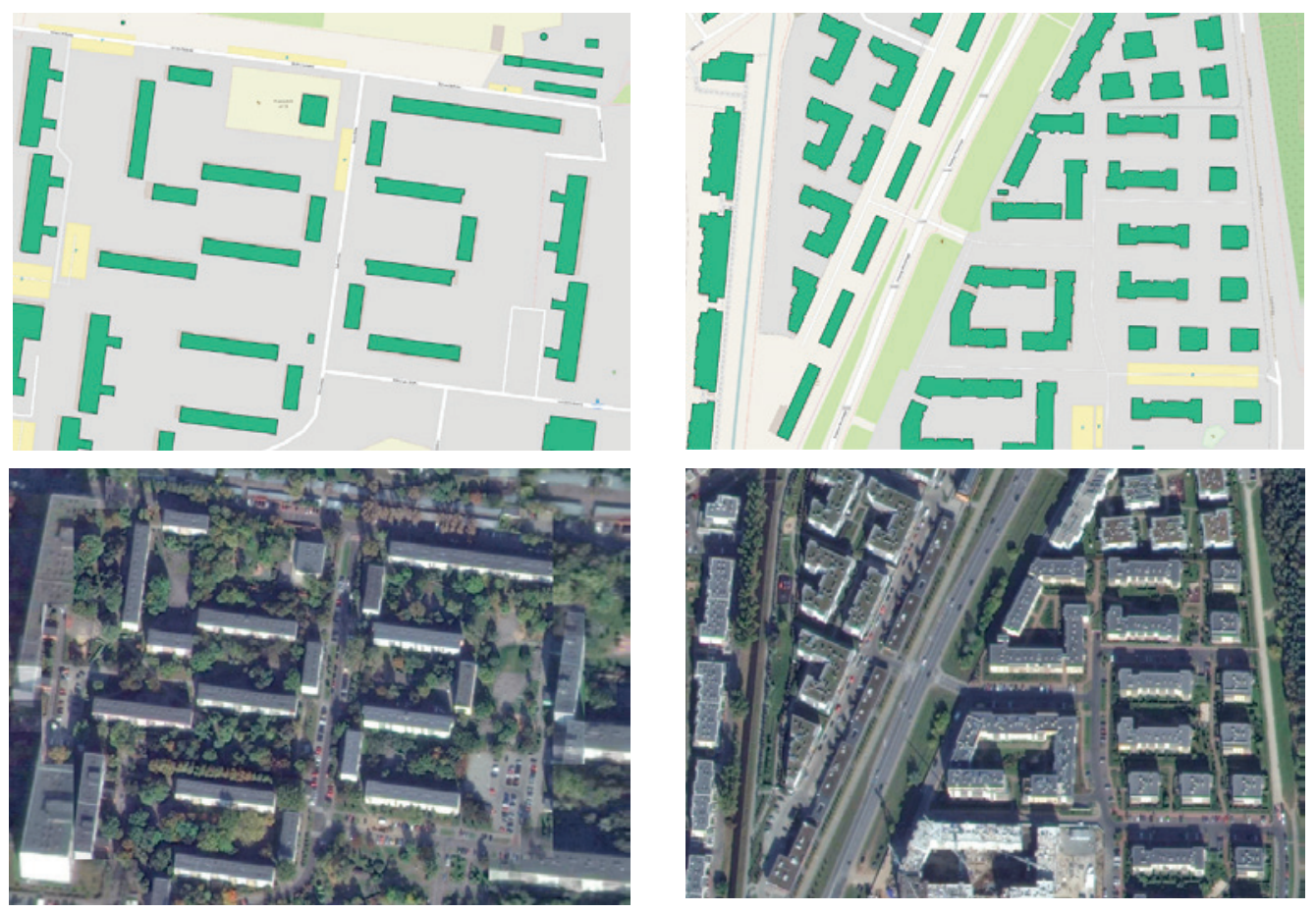

Figure 2. Differences between residential density between old (left panel) and new (right panel) residential projects in Warsaw (source: own elaboration based on openstreetmap.org and maps.google.com) 
in case of pre-transformation (socialist) housing estates (Masztalski \& Michalski, 2011).

While the literature reports that share of green areas in a neighborhood is positively linked with apartment prices (Czembrowski \& Kronenberg, 2016) substitution effect between small recreation green areas around a building and bigger public green areas (park or forests) in its proximity, as well as their joint influence on house prices has not been addressed sufficiently (see Section 1). In order to examine the relationship between residential development density and hedonic value of green urban areas, in addition to the standard hedonic regression model, we estimate separate quantile regression models for different types of housing stock. Szulczewska and Kaliszuk (2003) argue that urban planning in Warsaw faces a dilemma, as planners must choose between the idea of a compact city (thus limiting the urban green space within) or green city (thus allowing further urban sprawl).

\subsection{Data collection, variables}

This paper aims to determine the scope of the subject, which includes the secondary housing market relating to full ownership rights of private accommodation. This research refers to dwellings located in multi-family buildings (the majority of dwellings are located in multi-family residential apartment blocks and houses are characterized by great differentiation regarding both quantitative and qualitative features, which requires the database to include the appropriate information on each property in order to

Table 2. Qualitative and quantitative variables applied in the models (source: own elaboration)

\begin{tabular}{|c|c|c|c|}
\hline Variable & Category & Description & Symbol \\
\hline Area & $\mathrm{S}$ & Area of the dwelling & area \\
\hline $\begin{array}{l}\text { Construction } \\
\text { technology }\end{array}$ & S & $\begin{array}{l}1 \text { - if the dwelling is located in a building made with a } \\
\text { prefabricated technology, } \\
2 \text { - if the dwelling is located in a building made with } \\
\text { traditional technology. }\end{array}$ & technology \\
\hline $\begin{array}{l}\text { Time of } \\
\text { construction }\end{array}$ & $\mathrm{S}$ & $\begin{array}{l}6 \text { dummy variables. If the dwelling is located in a building } \\
\text { built in a given period, it takes the value } 1 \text {; otherwise it } \\
\text { takes } 0 .\end{array}$ & $\begin{array}{l}\text { cons1950 - built } 1950-1959^{\star} \\
\text { cons1960 - built 1960-1969 } \\
\text { cons1970 - built } 1970-1979 \\
\text { cons } 1980 \text { - built } 1980-1989 \\
\text { cons1990 - built } 1990-1999 \\
\text { cons } 2000 \text { - built after } 2000\end{array}$ \\
\hline Floor & $\mathrm{S}$ & $\begin{array}{l}3 \text { dummy variables. If the dwelling is located on a given } \\
\text { floor, it takes the value } 1 \text {; otherwise it takes } 0\end{array}$ & $\begin{array}{l}\text { floor1 - ground floor } \\
\text { floor2 - other floors } \\
\text { floor3 - first and second floor }\end{array}$ \\
\hline Height & S & $\begin{array}{l}\text { 1-buildings up to } 4 \text { floors } \\
\text { 2-buildings above } 5 \text { floors }\end{array}$ & height \\
\hline Basement & $\mathrm{S}$ & $\begin{array}{l}\text { A dummy variable, it takes the value } 1 \text { if the apartment } \\
\text { has basement or storage room; otherwise it takes } 0\end{array}$ & basement \\
\hline Garage & S & $\begin{array}{l}\text { It takes the value } 2 \text { if the apartment has individual } \\
\text { parking space in the garage; it takes value } 1 \text { if there is a } \\
\text { parking space outside the building. Otherwise it takes } 0\end{array}$ & garage \\
\hline Kindergarten & $\mathrm{N}$ & Distance to nearest kindergarten (in $\mathrm{km}$ ) & kindergarten \\
\hline School & $\mathrm{N}$ & Distance to nearest primary school (in km) & school \\
\hline Subway & $\mathrm{N}$ & Distance to nearest subway station (in km) & subway \\
\hline Duga & $\mathrm{N}$ & $\begin{array}{l}\text { Distance to the urban green area, } 6 \text { dummy variables. If } \\
\text { the dwelling is located within given distance band from } \\
\text { uga it takes the value } 1 \text {; otherwise it takes } 0\end{array}$ & $\begin{array}{l}\text { duga100 - distance } 0-100 \mathrm{~m}, \\
\text { duga200 - distance } 101-200 \mathrm{~m} \text {, } \\
\text { duga300 - distance } 201-300 \mathrm{~m}, \\
\text { duga400 - distance } 301-400 \mathrm{~m}, \\
\text { duga500 - distance } 401-500 \mathrm{~m} \text {, } \\
\text { duga500 distance }>500 \mathrm{~m}^{*} \\
\end{array}$ \\
\hline Dcc & $\mathrm{L}$ & Distance to city centre (in $\mathrm{km}$ ) & dcc \\
\hline District & $\mathrm{L}$ & $\begin{array}{l}18 \text { dummy variables. If an apartment is located in a given } \\
\text { district, it takes the value } 1 \text {; otherwise it takes } 0 .\end{array}$ & $\begin{array}{l}\text { d1-Bemowo, d2-Białołęka, d3-Bielany, } \\
\text { d4-Mokotów, d5-Ochota, d6-Praga } \\
\text { Południe, d7-Praga Północ, d8- } \\
\text { Rembertów, d9-Sródmieście*, d10- } \\
\text { Targówek, d11-Ursus, d12-Ursynów, } \\
\text { d13-Wawer, d14-Wesoła, d15-Wilanów, } \\
\text { d16-Włochy, d17-Wola, d18-Żoliborz }\end{array}$ \\
\hline Year & $\mathrm{T}$ & $\begin{array}{l}6 \text { time dummy variables used in the global model. If the } \\
\text { dwelling was sold in a given year, it takes the value } 1 \text {; } \\
\text { otherwise it takes } 0 .\end{array}$ & $\begin{array}{l}\text { y2010*, y2011, y2012, y2013, y2014, } \\
\text { y2015 }\end{array}$ \\
\hline
\end{tabular}

* base category. 
construct models that will not be biased because of a lowquality dataset). The research is based on transaction data. The sample is based on residential property sales from the 1st quarter of 2010 to the 4 th quarter of 2015. The data was obtained from Board of Geodesy and Municipal Cadastre in Warsaw. All non-market transactions (e.g. debt enforcement sales) were removed from the final dataset. Notarial contracts contain following information: transaction date, sales price, area of a dwelling, the floor on which a dwelling is located, and the area of any auxiliary premises (e.g. a garage/parking spot in an indoor parking lot or a cellar/ storage). On the other hand, notarial contracts do not include information on various price determinants such as construction technology, architecture, building quality. Using cadastre data, additional information was gathered on the height of buildings and the year of construction. Finally, using Street View application on maps.google.com, the missing data concerning the height, and most importantly building technology was added. Locations of transactions (exact addresses) were geocoded with google maps API. Based on WMS servers of the Warsaw City Hall, the vector layer of parks was prepared. In this research, we excluded apartments built before 1939. The reason for which was the fact that in the case of such apartments, the technical condition of a building is a significant determinant of their value (our base does not include this factor), which might burden the obtained results. Moreover, during the Second World War Warsaw was almost completely demolished, so the share of such transactions is very small (should not burden the results). The final dataset contained 43075 geo-coded apartments sold between 1q 2010 and 4q 2015 (Figure 1). Taking into account Dubin (1988) and Malpezzi (2008) suggestions three major categories of characteristics of dwellings may be distinguished: (1) structural attributes $S$, (2) neighbourhood related services and features $N$, (3) location and accessibility $L$. Additionally it is important to control for time $(T)$.

The choice of qualitative and quantitative data was limited by the availability of information gathered. Table 2 presents variables used in the study.

To conclude we controlled for various characteristics typically used in hedonic pricing models for residential market: location (administrative district), construction technology, floor, time of construction, area of an apartment, presence of a garage, presence of a basement, height of building, and distance to a city centre, a kindergarten, a primary school, a subway and an urban green areas. The summary statistics of variables are presented in Table 3.

The results of the hedonic models' estimation are presented in Section 3.

Table 3. Summary statistics of variables used in the research (source: own elaboration)

\begin{tabular}{|c|c|c|c|c|c|c|c|}
\hline Category & Variable & Mean & $\begin{array}{l}\text { Standard } \\
\text { deviation }\end{array}$ & Category & Variable & Mean & $\begin{array}{l}\text { Standard } \\
\text { deviation }\end{array}$ \\
\hline \multirow[t]{6}{*}{$\mathrm{T}$} & 2010 & 0.16 & 0.37 & \multirow[t]{16}{*}{$S$} & area & 52.86 & 24.23 \\
\hline & 2011 & 0.16 & 0.37 & & area2 & 3381.06 & 4089.24 \\
\hline & 2012 & 0.14 & 0.35 & & basement & 0.43 & 0.50 \\
\hline & 2013 & 0.17 & 0.38 & & cons 1950 & 0.18 & 0.38 \\
\hline & 2014 & 0.17 & 0.38 & & cons 1960 & 0.16 & 0.36 \\
\hline & 2015 & 0.19 & 0.39 & & cons 1970 & 0.11 & 0.31 \\
\hline \multirow[t]{19}{*}{$\mathrm{L}$} & $\mathrm{d} 1$ & 0.06 & 0.24 & & cons 1980 & 0.04 & 0.20 \\
\hline & $\mathrm{d} 2$ & 0.10 & 0.30 & & cons 1990 & 0.06 & 0.23 \\
\hline & $\mathrm{d} 3$ & 0.06 & 0.23 & & cons 2000 & 0.40 & 0.49 \\
\hline & $\mathrm{d} 4$ & 0.15 & 0.36 & & cons 2010 & 0.06 & 0.24 \\
\hline & d5 & 0.05 & 0.23 & & floor 1 & 0.13 & 0.34 \\
\hline & d6 & 0.10 & 0.30 & & floor2 & 0.51 & 0.50 \\
\hline & $\mathrm{d} 7$ & 0.03 & 0.17 & & floor3 & 0.36 & 0.48 \\
\hline & $\mathrm{d} 8$ & 0.01 & 0.09 & & garage & 0.42 & 0.66 \\
\hline & d9 & 0.09 & 0.28 & & height & 1.67 & 0.67 \\
\hline & $\mathrm{d} 10$ & 0.05 & 0.22 & & technology & 1.73 & 0.44 \\
\hline & d11 & 0.04 & 0.20 & \multirow[t]{9}{*}{$\mathrm{N}$} & kindergarten & 0.28 & 0.19 \\
\hline & $\mathrm{d} 12$ & 0.07 & 0.25 & & school & 0.45 & 0.29 \\
\hline & $\mathrm{d} 13$ & 0.01 & 0.11 & & subway & 2.78 & 2.48 \\
\hline & $\mathrm{d} 14$ & 0.01 & 0.09 & & duga100 & 0.06 & 0.24 \\
\hline & $\mathrm{d} 15$ & 0.03 & 0.18 & & duga200 & 0.11 & 0.31 \\
\hline & d16 & 0.02 & 0.13 & & duga300 & 0.12 & 0.32 \\
\hline & $\mathrm{d} 17$ & 0.10 & 0.30 & & duga400 & 0.11 & 0.32 \\
\hline & $\mathrm{d} 18$ & 0.02 & 0.14 & & duga500 & 0.10 & 0.30 \\
\hline & dcc & 6.31 & 3.37 & & duga501 & 0.50 & 0.50 \\
\hline
\end{tabular}




\subsection{Hedonic price models}

In a great number of researchers, the aim of which is to estimate the implicit price for each characteristic of a good, the hedonic method is used. Since Lancaster's (1966) and Rosen's (1974) seminal work, the hedonic method is widely employed in housing studies. Hedonic price models focus on the utility derived from individual characteristics of a good. The core of the hedonic methodology is the assumption that the price of any heterogeneous good (apartment in this study) is the function of its attributes (localisation, area, quality of an apartment). As housing is heterogeneous good, it is difficult to even indicate a full list of crucial attributes. In our study, we examine the implicit value of one of neighbourhood related environmental features, namely the proximity to the urban green area (duga). We hypothesise that transaction price is a function of a distance to the urban green area (duga), while controlling for other relevant structural (S), neighbourhood $(\mathrm{N})$, and location attributes $(\mathrm{L})$, as well as time (T). In general, the price is a hedonic function:

$$
\text { price }=f(\text { duga }, S, N, L, T) \text {. }
$$

In our research, we use a typical log-linear hedonic model specification, commonly used in the literature (Malpezzi, 2008). Regress apartment's price (natural logarithm of sales price) on a set of independent variables. Our baseline model is given by:

$$
\begin{aligned}
& \ln \text { price }_{=} \beta_{0}+\beta_{1} d u g a_{100}+\beta_{2} d u g a_{200}+\beta_{3} d u g a_{300}+ \\
& \beta_{4} d u g a_{400}+\beta_{5} d u g a_{500}+\sum \theta_{k} S_{k}+\sum \omega_{m} N_{m}+ \\
& \sum \gamma_{i} L_{i}+\sum \tau_{j} T_{j}+\varepsilon .
\end{aligned}
$$

In this research, we used several variants of hedonic regression, namely standard Ordinary Least Squares (OLS), robust Weighted Least Squares (WLS) and Median Quantile Regression (Median QR) models. We use different estimation techniques to ensure the results are robust and reliable. The housing literature is quite consistent on treating housing as heterogeneous in several dimensions. From econometric (or data analysis) perspective, this heterogeneity can create heteroscedasticity in the residuals, while estimating the price function using standard OLS. Therefore, we decided to address the problem using different analytical approaches. Firstly, a robust model, employing OLS with heteroscedasticity-correction (WLS) was estimated. Secondly, we decided to employ median quantile regression. The quantile regression relies on minimisation of weighted absolute deviations, and during the process, conditional quantiles (percentile) functions are estimated (Koenker \& Bassett, 1978; Koenker \& Hallock, 2001). The quantile regression involves weighing, both symmetric (for the median, quantile $=0.5$ ), and asymmetric (for all other quantiles). In this research we decided to use symmetric weighting (quantile-0.5). Within the quantile regression approach, there is no limitation imposed on explaining the mean of the dependent variable. The quantile regression is more flexible, as it can be employed to explain the implicit prices of housing attributes at any point of the distribution of the dependent variable, thus for low-priced, mediumpriced, and high-priced properties (J. Zietz, E. Zietz, \& Sirmans, 2008).

The mechanism to perform the quantile regression is similar to ordinary regression. The difference in the mechanism to perform the quantile regression to ordinary regression lies in the way of searching for the margin of sums of squared residuals; the quantile regression looks for the margin of weighted sums of absolute residuals. There are several theoretical advantages of a hedonic quantile regression reported in the literature. The technique can be particularly useful in case of heteroscedasticity, outliers, and unobserved heterogeneity found in the empirical data on housing transactions (Liao \& Wang, 2012).

Due to the high number of independent variables available, multicollinearity may be a serious concern. Multicollinearity leads to unstable coefficients and inflated standard errors. The Variance Inflation Factors (VIFs) was used to detect it. The VIF values in models do not exceed 6.8 which is in line with the most conservative rules of thumb that the mean of the VIFs should not be considerably larger than 10 .

\section{Results}

We estimated two groups of regression models. The first group of models, later referred to as a general model, is based on the whole sample of housing transactions conducted in Warsaw (apartments built after 1950). The second group of models was based on the same sample. However, new variables were introduced to track the influence of a construction period (different housing estate) on proximity to the urban green area. The estimation results for the general model is presented in Table 4.

As a robustness check, alongside baseline OLS model we used WLS and quantile regression. The results are relatively similar, albeit we found several differences regarding statistical significance for selected parameters. The estimates discussed below refer to quantile regression model.

In our study nominal prices were used (we did not correct for inflation) and we observed that within the period under study (2010-2015), the time had a significant impact on transaction prices. It is worth mentioning that housing prices in the biggest cities in Poland increased by about 100\% between 2006 and 2007 (Trojanek, 2012). At the end of 2007, the subsequent decreasing phase in the house price cycle began resulting from this abnormal price increase and the beginning of the financial crisis.

The regression coefficients of the locational variables (districts) can be interpreted as district values. In this research, the base variable was $d 9$ corresponding to the Downtown district. Statistically significant negative coefficients of regression of other districts confirmed the fact that consumers for apartments in the city centre are willing to pay more (Trojanek, 2015).

In general, the relations between physical characteristics of apartments and sales prices were consistent with expectations. Additionally, we found that the increase 
Table 4. Estimation results - general mode (dependent variable is natural logarithm of sale price) (source: own elaboration)

\begin{tabular}{|c|c|c|c|c|c|c|}
\hline \multirow[b]{2}{*}{ Variable } & \multicolumn{2}{|c|}{ OLS } & \multicolumn{2}{|c|}{ WLS } & \multicolumn{2}{|c|}{ Median QR } \\
\hline & Coefficient & Probability & Coefficient & Probability & Coefficient & Probability \\
\hline const & 11.9593 & 0.0001 & 11.8682 & 0.0001 & 11.9052 & 0.0001 \\
\hline Y2011 & -0.0071 & 0.0130 & -0.0071 & 0.0027 & -0.0088 & 0.0011 \\
\hline Y2012 & -0.0805 & 0.0001 & -0.0809 & 0.0001 & -0.0788 & 0.0001 \\
\hline Y2013 & -0.1290 & 0.0001 & -0.1282 & 0.0001 & -0.1261 & 0.0001 \\
\hline Y2014 & -0.0987 & 0.0001 & -0.0995 & 0.0001 & -0.0981 & 0.0001 \\
\hline Y2015 & -0.0907 & 0.0001 & -0.0951 & 0.0001 & -0.0922 & 0.0001 \\
\hline $\mathrm{d} 1$ & -0.1572 & 0.0001 & -0.1490 & 0.0001 & -0.1358 & 0.0001 \\
\hline $\mathrm{d} 2$ & -0.2174 & 0.0001 & -0.2347 & 0.0001 & -0.2115 & 0.0001 \\
\hline $\mathrm{d} 3$ & -0.1479 & 0.0001 & -0.1553 & 0.0001 & -0.1393 & 0.0001 \\
\hline $\mathrm{d} 4$ & -0.0746 & 0.0001 & -0.0802 & 0.0001 & -0.0687 & 0.0001 \\
\hline $\mathrm{d} 5$ & -0.1553 & 0.0001 & -0.1396 & 0.0001 & -0.1291 & 0.0001 \\
\hline d6 & -0.1708 & 0.0001 & -0.1690 & 0.0001 & -0.1578 & 0.0001 \\
\hline $\mathrm{d} 7$ & -0.2860 & 0.0001 & -0.2837 & 0.0001 & -0.2705 & 0.0001 \\
\hline $\mathrm{d} 8$ & -0.1126 & 0.0001 & -0.1154 & 0.0001 & -0.0987 & 0.0001 \\
\hline $\mathrm{d} 10$ & -0.2220 & 0.0001 & -0.2142 & 0.0001 & -0.2046 & 0.0001 \\
\hline $\mathrm{d} 11$ & -0.1309 & 0.0001 & -0.1258 & 0.0001 & -0.1021 & 0.0001 \\
\hline $\mathrm{d} 12$ & -0.0102 & 0.2429 & -0.0244 & 0.0018 & 0.0013 & 0.8743 \\
\hline $\mathrm{d} 13$ & -0.1069 & 0.0001 & -0.0993 & 0.0001 & -0.0870 & 0.0001 \\
\hline $\mathrm{d} 14$ & 0.0177 & 0.2303 & 0.0182 & 0.1767 & 0.0478 & 0.0006 \\
\hline $\mathrm{d} 15$ & -0.1504 & 0.0001 & -0.1186 & 0.0001 & -0.1221 & 0.0001 \\
\hline $\mathrm{d} 16$ & -0.2111 & 0.0001 & -0.1911 & 0.0001 & -0.1733 & 0.0001 \\
\hline $\mathrm{d} 17$ & -0.1953 & 0.0001 & -0.1859 & 0.0001 & -0.1758 & 0.0001 \\
\hline $\mathrm{d} 18$ & -0.0651 & 0.0001 & -0.0797 & 0.0001 & -0.0685 & 0.0001 \\
\hline area & 0.0227 & 0.0001 & 0.0256 & 0.0001 & 0.0242 & 0.0001 \\
\hline area $^{2}$ & -0.0001 & 0.0001 & -0.0001 & 0.0001 & -0.0001 & 0.0001 \\
\hline basement & 0.0294 & 0.0001 & 0.0204 & 0.0001 & 0.0216 & 0.0001 \\
\hline cons 1960 & 0.0147 & 0.0001 & 0.0154 & 0.0001 & 0.0180 & 0.0001 \\
\hline cons 1970 & 0.0341 & 0.0001 & 0.0245 & 0.0001 & 0.0307 & 0.0001 \\
\hline cons 1980 & 0.0608 & 0.0001 & 0.0371 & 0.0001 & 0.0415 & 0.0001 \\
\hline cons 1990 & 0.1354 & 0.0001 & 0.1310 & 0.0001 & 0.1366 & 0.0001 \\
\hline cons 2000 & 0.2273 & 0.0001 & 0.2079 & 0.0001 & 0.2139 & 0.0001 \\
\hline cons 2010 & 0.2213 & 0.0001 & 0.2210 & 0.0001 & 0.2059 & 0.0001 \\
\hline floor2 & 0.0269 & 0.0001 & 0.0256 & 0.0001 & 0.0269 & 0.0001 \\
\hline floor3 & 0.0284 & 0.0001 & 0.0288 & 0.0001 & 0.0302 & 0.0001 \\
\hline garage & 0.0291 & 0.0001 & 0.0250 & 0.0001 & 0.0267 & 0.0001 \\
\hline height & -0.0061 & 0.0001 & -0.0037 & 0.0063 & -0.0026 & 0.0757 \\
\hline technology & 0.0497 & 0.0001 & 0.0482 & 0.0001 & 0.0484 & 0.0001 \\
\hline $\mathrm{dcc}$ & -0.0268 & 0.0001 & -0.0217 & 0.0001 & -0.0233 & 0.0001 \\
\hline kindergarten & -0.0119 & 0.0131 & -0.0029 & 0.5049 & -0.0081 & 0.0718 \\
\hline school & -0.0352 & 0.0001 & -0.0288 & 0.0001 & -0.0307 & 0.0001 \\
\hline subway & -0.0160 & 0.0001 & -0.0188 & 0.0001 & -0.0186 & 0.0001 \\
\hline duga100 & 0.0452 & 0.0001 & 0.0276 & 0.0001 & 0.0304 & 0.0001 \\
\hline duga200 & 0.0145 & 0.0001 & 0.0138 & 0.0001 & 0.0077 & 0.0042 \\
\hline duga300 & 0.0120 & 0.0001 & 0.0069 & 0.0044 & 0.0065 & 0.0126 \\
\hline duga400 & 0.0074 & 0.0074 & 0.0021 & 0.3788 & 0.0028 & 0.2807 \\
\hline duga500 & 0.0056 & 0.0510 & 0.0015 & 0.5372 & 0.0029 & 0.2778 \\
\hline R-squared & \multicolumn{2}{|c|}{0.8702} & \multicolumn{2}{|c|}{0.8495} & \multicolumn{2}{|c|}{-} \\
\hline $\mathrm{N}$ & \multicolumn{2}{|c|}{43075} & \multicolumn{2}{|c|}{43075} & \multicolumn{2}{|c|}{43075} \\
\hline
\end{tabular}


in distance from the city centre negatively affects the value of the apartment. The negative relation between the distance and a property price was also observed in case of a kindergarten, a primary school and a subway station (Trojanek \& Gluszak, 2017). What is important, estimation results confirm the findings from earlier studies in Poland which suggest that the proximity to an urban green area has a positive impact on property values (Zygmunt \& Gluszak, 2015; Czembrowski \& Kronenberg, 2016; Trojanek, 2016).

The results suggest that proximity to urban green has a significant positive impact on apartments' prices up within 400 metres distance, and the reported price premiums were the highest within 100 meters distance band. The effect is statistically insignificant beyond this distance threshold. These findings are also in line with the existing body of evidence, which suggests that urban green affects property process within 500-600 meters radius, and the values of adjacent properties are affected the most (Lutzenhiser \& Netusil, 2001; McCord et al., 2014).

On average the distance to urban green areas has a significant nonlinear impact on residential prices. Direct proximity to a park or an urban forest (up to 100-meter distance) increased apartment sale prices by $2.8 \%-3.1 \%$ (depending on a model) compared with apartments lo- cated outside 500 distance band. The premium declined with distance - apartments located in the second distance band (100-200 meters, thus relatively close, but not in direct proximity to the urban green) were still sold for a higher price than comparable apartments situated further from the green area, but the difference was only by about $1.0 \%$. The premium had somewhat steep distance decay function - proximity to the urban green did not affect significantly sales prices of otherwise comparable apartments located outside 400 meters distance band from urban green. The result can be intuitively explained - it is worth to pay for proximity to the park/forest only if it is easily accessible (a short walk from the building entrance, plus sometimes a relaxing view from the apartment). If the trip to the park/forest demands longer walk/drive the direct benefits from urban green will diminish.

To discuss the impact of an urban green on a housing value of different housing estates, we estimated an alternative model with interaction terms. We interacted distance to an urban green (duga) with period ${ }_{1}$ and period dummy variables. Variable period ${ }_{1}$ takes value 1 if the dwelling was built during the years 1950-1989, otherwise it takes 0 . Analogously, period ${ }_{2}$ is equal to 1 if the dwelling was built after 1989, and 0 otherwise. The models were estimated again, and the results were presented in Table 5.

Table 5. Hedonic regression estimation results (dependent variable is natural logarithm of sale price) (source: own elaboration)

\begin{tabular}{|c|c|c|c|c|c|c|}
\hline \multirow[b]{2}{*}{ Variable } & \multicolumn{2}{|c|}{ OLS } & \multicolumn{2}{|c|}{ WLS } & \multicolumn{2}{|c|}{ Median QR } \\
\hline & Coefficient & Probability & Coefficient & Probability & Coefficient & Probability \\
\hline const & 11.9685 & 0.0001 & 11.8746 & 0.0001 & 11.9074 & 0.0001 \\
\hline Y2011 & -0.0068 & 0.0174 & -0.0070 & 0.0031 & -0.0079 & 0.0024 \\
\hline Y2012 & -0.0805 & 0.0001 & -0.0810 & 0.0001 & -0.0796 & 0.0001 \\
\hline Y2013 & -0.1291 & 0.0001 & -0.1283 & 0.0001 & -0.1274 & 0.0001 \\
\hline Y2014 & -0.0989 & 0.0001 & -0.0996 & 0.0001 & -0.0984 & 0.0001 \\
\hline Y2015 & -0.0905 & 0.0001 & -0.0951 & 0.0001 & -0.0913 & 0.0001 \\
\hline $\mathrm{d} 1$ & -0.1602 & 0.0001 & -0.1521 & 0.0001 & -0.1387 & 0.0001 \\
\hline $\mathrm{d} 2$ & -0.2198 & 0.0001 & -0.2363 & 0.0001 & -0.2118 & 0.0001 \\
\hline d3 & -0.1451 & 0.0001 & -0.1533 & 0.0001 & -0.1354 & 0.0001 \\
\hline $\mathrm{d} 4$ & -0.0747 & 0.0001 & -0.0801 & 0.0001 & -0.0673 & 0.0001 \\
\hline d5 & -0.1547 & 0.0001 & -0.1396 & 0.0001 & -0.1284 & 0.0001 \\
\hline $\mathrm{d} 6$ & -0.1753 & 0.0001 & -0.1712 & 0.0001 & -0.1599 & 0.0001 \\
\hline $\mathrm{d} 7$ & -0.2900 & 0.0001 & -0.2869 & 0.0001 & -0.2738 & 0.0001 \\
\hline $\mathrm{d} 8$ & -0.1253 & 0.0001 & -0.1230 & 0.0001 & -0.1083 & 0.0001 \\
\hline $\mathrm{d} 10$ & -0.2259 & 0.0001 & -0.2180 & 0.0001 & -0.2056 & 0.0001 \\
\hline d11 & -0.1345 & 0.0001 & -0.1295 & 0.0001 & -0.1051 & 0.0001 \\
\hline $\mathrm{d} 12$ & -0.0041 & 0.6345 & -0.0188 & 0.0161 & 0.0069 & 0.3836 \\
\hline d13 & -0.1136 & 0.0001 & -0.1062 & 0.0001 & -0.0902 & 0.0001 \\
\hline d14 & 0.0008 & 0.9589 & 0.0067 & 0.6314 & 0.0368 & 0.0063 \\
\hline d15 & -0.1449 & 0.0001 & -0.1153 & 0.0001 & -0.1161 & 0.0001 \\
\hline $\mathrm{d} 16$ & -0.2159 & 0.0001 & -0.1961 & 0.0001 & -0.1771 & 0.0001 \\
\hline d17 & -0.1972 & 0.0001 & -0.1881 & 0.0001 & -0.1763 & 0.0001 \\
\hline $\mathrm{d} 18$ & -0.0620 & 0.0001 & -0.0749 & 0.0001 & -0.0631 & 0.0001 \\
\hline area & 0.0227 & 0.0001 & 0.0257 & 0.0001 & 0.0243 & 0.0001 \\
\hline area $^{2}$ & -0.0001 & 0.0001 & -0.0001 & 0.0001 & -0.0001 & 0.0001 \\
\hline basement & 0.0287 & 0.0001 & 0.0198 & 0.0001 & 0.0215 & 0.0001 \\
\hline cons 1960 & 0.0144 & 0.0002 & 0.0143 & 0.0001 & 0.0181 & 0.0001 \\
\hline
\end{tabular}


End of Table 5

\begin{tabular}{|c|c|c|c|c|c|c|}
\hline \multirow[b]{2}{*}{ Variable } & \multicolumn{2}{|c|}{ OLS } & \multicolumn{2}{|c|}{ WLS } & \multicolumn{2}{|c|}{ Median QR } \\
\hline & Coefficient & Probability & Coefficient & Probability & Coefficient & Probability \\
\hline cons1970 & 0.0342 & 0.0001 & 0.0238 & 0.0001 & 0.0297 & 0.0001 \\
\hline cons 1980 & 0.0564 & 0.0001 & 0.0328 & 0.0001 & 0.0408 & 0.0001 \\
\hline cons 1990 & 0.1197 & 0.0001 & 0.1190 & 0.0001 & 0.1237 & 0.0001 \\
\hline cons 2000 & 0.2116 & 0.0001 & 0.1960 & 0.0001 & 0.2026 & 0.0001 \\
\hline cons 2010 & 0.2074 & 0.0001 & 0.2098 & 0.0001 & 0.1949 & 0.0001 \\
\hline floor2 & 0.0268 & 0.0001 & 0.0254 & 0.0001 & 0.0267 & 0.0001 \\
\hline floor3 & 0.0281 & 0.0001 & 0.0288 & 0.0001 & 0.0305 & 0.0001 \\
\hline garage & 0.0293 & 0.0001 & 0.0256 & 0.0001 & 0.0265 & 0.0001 \\
\hline height & -0.0059 & 0.0002 & -0.0038 & 0.0046 & -0.0023 & 0.1029 \\
\hline technology & 0.0495 & 0.0001 & 0.0476 & 0.0001 & 0.0492 & 0.0001 \\
\hline $\mathrm{dcc}$ & -0.0270 & 0.0001 & -0.0219 & 0.0001 & -0.0237 & 0.0001 \\
\hline kindergarten & -0.0117 & 0.0145 & -0.0024 & 0.5690 & -0.0082 & 0.0596 \\
\hline school & -0.0354 & 0.0001 & -0.0290 & 0.0001 & -0.0294 & 0.0001 \\
\hline subway & -0.0146 & 0.0001 & -0.0176 & 0.0001 & -0.0175 & 0.0001 \\
\hline period $_{1} \mathrm{x}$ duga 100 & -0.0037 & 0.4587 & -0.0057 & 0.1814 & 0.0022 & 0.6303 \\
\hline period $_{1} \mathrm{x}$ duga200 & -0.0015 & 0.6965 & 0.0020 & 0.5545 & -0.0034 & 0.3284 \\
\hline period $_{1} \mathrm{x}$ duga300 & 0.0009 & 0.8070 & -0.0001 & 0.9685 & -0.0017 & 0.6198 \\
\hline period $_{1} \mathrm{x}$ duga 400 & -0.0009 & 0.8015 & -0.0046 & 0.1672 & -0.0043 & 0.1940 \\
\hline period $_{1} \mathrm{x}$ duga500 & 0.0042 & 0.2963 & 0.0015 & 0.6614 & 0.0002 & 0.9484 \\
\hline period $_{2} \mathrm{x}$ duga 100 & 0.0993 & 0.0001 & 0.0768 & 0.0001 & 0.0826 & 0.0001 \\
\hline period $_{2} \mathrm{x}$ duga200 & 0.0310 & 0.0001 & 0.0273 & 0.0001 & 0.0208 & 0.0001 \\
\hline period $_{2} \mathrm{x}$ duga300 & 0.0220 & 0.0001 & 0.0136 & 0.0002 & 0.0147 & 0.0001 \\
\hline period $_{2} \mathrm{x}$ duga400 & 0.0139 & 0.0008 & 0.0084 & 0.0191 & 0.0111 & 0.0032 \\
\hline period $_{2} \mathrm{x}$ duga 500 & 0.0040 & 0.3152 & 0.0003 & 0.9339 & 0.0051 & 0.1665 \\
\hline R-squared & \multicolumn{2}{|c|}{0.8709} & \multicolumn{2}{|c|}{0.8498} & \multicolumn{2}{|l|}{ 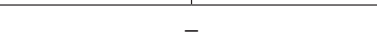 } \\
\hline $\mathrm{N}$ & \multicolumn{2}{|c|}{43075} & \multicolumn{2}{|c|}{43075} & \multicolumn{2}{|c|}{43075} \\
\hline
\end{tabular}

The results of the second group models estimation (with variables which should distinguish the influence of proximity to an urban green area on different housing estate) provide interesting results. On an average proximity to an urban green areas did not have a significant impact on sale prices (neither in OLS, not WLS and Median QR model) in case of apartments built in years 1950-1989. Even immediate proximity (an urban green area located within 100 meters from the apartment) did not influence house prices. No significant (at alpha $=0.05$ ) difference was observed for other distance bands.

The results differed significantly in case of building constructed after 1989. The impact of an urban green was particularly strong in case of post-transformation housing stock. Close vicinity (less than $100 \mathrm{~m}$ distance) to urban green increased the sales prices of apartments in new residential buildings by $8.0-8.6 \%$, depending on a model. It did not have a significant impact in case of apartments located in socialist housing estates. The empirical results provide arguments in support of the research hypothesis. Apparently, relative lack of green areas around buildings and dense development typical for post-transformation residential development increases the hedonic value of public urban green areas. In the Figure 3 duga's regression coefficients of quantile models are presented.
We believe that this finding can have interesting policy implications. It is easy to dismiss positive effects of urban green areas when the city is relatively green. Increasing demand for residential land and chaotic housing development resulted in a decrease of green areas at the urban fringe, where most of the new housing projects have been located. The relative shortage of green areas has increased the implicit price of proximity to parks and urban forests in Coef.

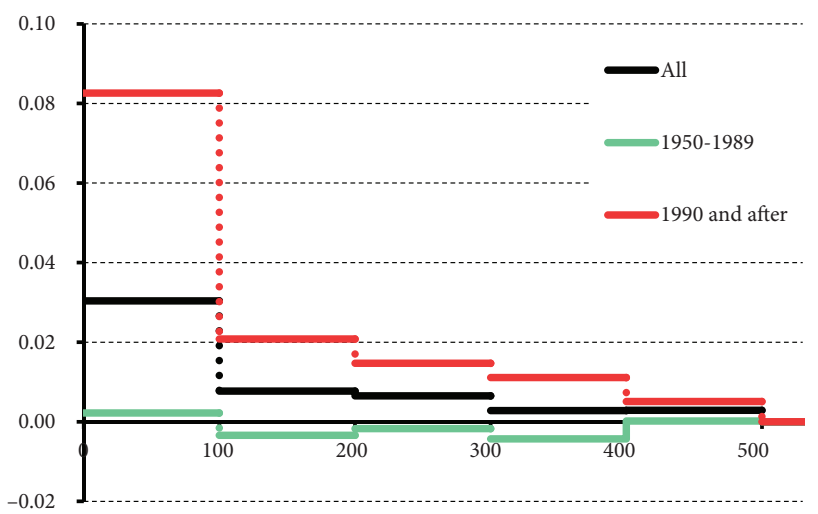

Distance to urban green area

Figure 3. Regression coefficients of distance to urban green areas (quantile models) (source: own elaboration) 
Warsaw. The residential value increase around parks and value can be captured in property taxes, but currently, this option is not exploited (in Poland nowadays property taxes are based on the size of a dwelling, not on its value - the location does not influence the tax amount). Currently, the tax system in Poland does not allow to link taxation with property value directly. Although the law allows for tax rate differentiation (based on location and other factors), in practice tax rates in most of the cities in Poland (Warsaw included) are set uniformly at a highest possible level for residential property (thus no differentiation is possible if we want to increase revenues). The increase in revenues from property tax revenues could be used to establish and maintain urban green and recreational areas, that would generate positive externalities and help to mitigate the negative effects of air pollution, typical to major cities in Poland.

\section{Conclusions}

We found strong evidence that proximity to a park is positively linked with apartment prices what is in line with previous studies. On the average presence of an urban green area within 100 meters from apartment increases the price of the dwelling by $2.8 \%$ to $3.1 \%$. However, the effect of park/forest proximity on house prices is more significant for newer apartments than those built before 1989. We found that proximity to a park is particularly important (and has a higher implicit price as a result) in the case of buildings constructed after 1989. Modern residential buildings are located smaller lots and built accordingly to the density maximisation principle (both regarding floor area ration and building coverage ratio). As a result, green areas within gated communities are often limited and can be treated like a club good, available only to residents. In that context, proximity to a publicly accessible green area outside the gates, only within a short walking distance is highly beneficial and translates into a significantly higher price of subject apartments.

We did not find a significant effect of urban green proximity on prices of apartments located in housing estates built during the years 1950-1989. This somewhat surprising result may stem from the fact that contrary to modern residential buildings there is an abundance of green areas (children playgrounds, recreation facilities, convenient walking paths) within housing estates for public use. Presence of additional public park in proximity may not result in significantly higher residential satisfaction, and as a consequence will not be capitalised in apartment price.

The latter result may shed new light on previous findings, notably Trojanek (2016) and Czembrowski and Kronenberg (2016), that overlooked potential differences in hedonic prices of urban green areas for different types of housing estates. The results may be interesting for (i) housing developers, providing incentives for better location choices regarding residential projects, as well as for (ii) urban planners, providing arguments to protect and maintain existing parks and green belts in the city.

\section{References}

Anderson, L. M., \& Cordell, H. K. (1998). Influence of trees on residential property values in Athens, Gerogia (U.S.A.): a survey based on actual sales prices. Landscape and Urban Planning, 15(1-2), 153-164. https://doi.org/10.1016/0169-2046(88)90023-0

Anderson, S. T. (2000). The effect of open space on single-family, residential home property values. Macalester Journal of Economics, 10, 261-270.

Bark, R. H., Osgood, D. E., Colby, B. G., \& Halper, E. B. (2011). How do homebuyers value different types of green space?. Journal of Agricultural and Resource Economics, 36(2), 395415. http://jareonline.org.

Bertaud, A., \& Bertaud, M. A. (2000). The spatial development of Warsaw Metropolitan area. Comments on Warsaw Development Strategy until the Year 2010 prepared for the World Bank, 11 June 2000.

Biao, Z., Gaodi, X., Bin, X., \& Canqiang, Z. (2012). The effects of public green spaces on residential property value in Beijing. Journal of Resources and Ecology, 3(3), 243-252. https://doi.org/10.5814/j.issn.1674-764x.2012.03.007

Bolitzer, B., \& Netusil, N. R. (2000). The impact of open spaces on property values in Portland, Oregon. Journal of Environmental Management, 59(3), 185-193.

https://doi.org/10.1006/jema.2000.0351

Conway, D., Li, C. Q., Wolch, J., Kahle, C., \& Jerrett, M. (2010). A spatial autocorrelation approach for examining the effects of urban greenspace on residential property values. Journal of Real Estate Finance and Economics, 41(2), 150-169.

https://doi.org/10.1007/s11146-008-9159-6

Crompton, J. L. (2001). The impact of parks on property values: a review of the empirical evidence. Journal of Leisure Research, 33(1), 1-31. https://doi.org/10.1080/13606710500348060

Crompton, J. L. (2005). The impact of parks on property values: empirical evidence from the past two decades in the United States. Managing Leisure, 10(4), 203-218.

https://doi.org/10.1080/13606710500348060

Czembrowski, P., \& Kronenberg, J. (2016). Hedonic pricing and different urban green space types and sizes: insights into the discussion on valuing ecosystem services. Landscape and Urban Planning, 146, 11-19.

https://doi.org/10.1016/j.landurbplan.2015.10.005

Des Rosiers, F., Thériault, M., Kestens, Y., \& Villeneuve, P. (2002). Landscaping and house values: an empirical investigation. Journal of Real Estate Research, 23(1/2), 139.

Degórska, B. (2012). Spatial growth of urbanised land within the Warsaw Metropolitan Area in the first decade of the 21st century. Geographia Polonica, 85(3), 77-95.

https://doi.org/10.7163/GPol.2012.3.19

Do, A. Q., \& Grudnitski, G. (1995). Golf-courses and residential house prices - an empirical-examination. Journal of Real Estate Finance and Economics, 10(3), 261-270.

https://doi.org/10.1007/BF01096941

Dombrow, J., Rodriguez, M., \& Sirmans, C. F. (2000). The market value of mature trees in single-family housing markets. Appraisal Journal, 68(1), 39-43.

Doss, C. R., \& Taff, S. J. (1996). The influence of wetland type and wetland proximity on residential property values. Journal of Agricultural and Resource Economics, 21(1), 120-129.

Dubin, R. A. (1988). Estimation of regression coefficients in the presence of spatially autocorrelated error terms. The Review of Economics and Statistics, 70(3), 466.

https://doi.org/10.2307/1926785 
Earnhart, D. (2001). Combining revealed and stated preference methods to value environmental amenities at residential locations. Land Economics, 77(1), 12-29.

https://doi.org/10.2307/3146977

Espey, M., \& Owusu-Edusei, K. (2001). Neighborhood parks and residential property values in Greenville, South Carolina. Journal of Agricultural and Applied Economics, 33(3), 487-492.

Gluszak, M., \& Marona, B. (2017). Discrete choice model of residential location in Krakow. Journal of European Real Estate Research, 10(1), 4-16.

https://doi.org/10.1108/JERER-01-2016-0006

Grey, G. W., \& Deneke, F. J. (1978). Urban forestry. Wiley.

Hendon, W. S. (1971). The park as a determinant of property values. American Journal of Economics and Sociology, 30(3), 289-300. https://doi.org/10.1111/j.1536-7150.1971.tb03232.x

Herath, S., Choumert, J., \& Maier, G. (2015). The value of the greenbelt in Vienna: a spatial hedonic analysis. Annals of Regional Science, 54(2), 349-374. https://doi.org/10.1007/s00168-015-0657-1

Hoshino, T., \& Kuriyama, K. (2010). Measuring the benefits of neighbourhood park amenities: application and comparison of spatial hedonic approaches. Environmental and Resource Economics, 45(3), 429-444. https://doi.org/10.1007/s10640-009-9321-5

Jim, C. Y., \& Chen, W. Y. (2010). External effects of neighbourhood parks and landscape elements on high-rise residential value. Land Use Policy, 27(2), 662-670. https://doi.org/10.1016/j.landusepol.2009.08.027

Kim, J.-H., Li, W., Newman, G., Kil, S.-H., \& Park, S. Y. (2016). The influence of urban landscape spatial patterns on singlefamily housing prices. Environment and planning B: Urban Analytics and City Science, 45(1), 26-43.

https://doi.org/10.1177/0265813516663932

Knetsch, J. L. (1964). The Influence of Reservoir Projects on Land Values. American Journal of Agricultural Economics, 46(1), 231-243. https://doi.org/10.2307/1236486

Koenker, R., \& Bassett, G. (1978). Regression quantiles. Econometrica, 46(1), 33-50. https://doi.org/10.2307/1913643

Koenker, R., \& Hallock, K. F. (2001). Quantile regression. Journal of Economic Perspectives, 15(4), 143-156.

https://doi.org/10.1257/jep.15.4.143

Kolbe, J., \& Wüstemann, H. (2014). Estimating the value of urban green space: a hedonic pricing analysis of the housing market in Cologne, Germany. Acta Universitatis Lodziensis Folia Oeconomica, 5(307), 45-61.

Konijnendijk, C., Annerstedt, M., Maruthaveeran, S., \& Nielsen, A. B. (2013). Benefits of urban parks a systematic review - A Report for IFPRA. IPFRA.

Kusiak, J. (2012). The cunning of chaos and its orders: a taxonomy of urban chaos in Post-Socialist Warsaw and beyond. Chasing Warsaw: Socio-Material Dynamics of Urban Change since 1990. Campus Verlag GmbH.

Lancaster, K. J. (1966). A new approach to consumer theory. Journal of Political Economy, 74(2), 132-157. https://doi.org/10.1086/259131

Laurie, I. C. (1979). Nature in cities: the natural environment in the design and development of urban green space. Wiley.

Lee, C.-M., \& Linneman, P. (1998). Dynamics of the greenbelt amenity effect on the land market-the case of Seoul's Greenbelt. Real Estate Economics, 26(1), 107-129.

https://doi.org/10.1111/1540-6229.00740

Liao, W. C., Wang, X. (2012). Hedonic house prices and spatial quantile regression. Journal of Housing Economics, 21(1), 16-27. https://doi.org/10.1016/j.jhe.2011.11.001

Liebelt, V., Bartke, S., \& Schwarz, N. (2018). Hedonic pricing analysis of the influence of urban green spaces onto residen- tial prices: the case of Leipzig, Germany. European Planning Studies, 26(1), 133-157.

https://doi.org/10.1080/09654313.2017.1376314

Luttik, J. (2000). The value of trees, water and open space as reflected by house prices in the Netherlands. Landscape and Urban Planning, 48(3-4), 161-167.

https://doi.org/10.1016/S0169-2046(00)00039-6

Lutzenhiser, M., \& Netusil, N. R. (2001). The effect of open spaces on a home's sale price. Contemporary Economic Policy, 19(3), 291-298. https://doi.org/10.1093/cep/19.3.291

Mahan, B. L., Polasky, S., \& Adams, R. M. (2000). Valuing urban wetlands: a property price approach. Land Economics, 76(1), 100-113. https://doi.org/10.2307/3147260

Malpezzi, S. (2008). Hedonic pricing models: a selective and applied review. In T. O'Sullivan \& K. Gibb (Eds.), Housing economics and public policy (pp.67-89). Wiley Online Library. https://doi.org/10.1002/9780470690680.ch5

Mantey, D. (2017). The 'publicness' of suburban gathering places: The example of Podkowa Leśna (Warsaw urban region, Poland). Cities, 60, 1-12. https://doi.org/10.1016/j.cities.2016.07.002

Masztalski, R. P., \& Michalski, M. (2011). Contemporary Housing Indicators in Poland on the Wroclaw Study Case. International Journal of Civil, Environmental, Structural, Construction and Architectural Engineering, 5(5), 247-254.

McConnell, V., \& Walls, M. A. (2005). The value of open space: evidence from studies of Nonmarket Benefits. Resources for the future.

McCord, J., McCord, M., McCluskey, W., Davis, P. T., McIlhatton, D., \& Haran, M. (2014). Effect of public green space on residential property values in Belfast metropolitan area. Journal of Financial Management of Property and Construction, 19(2), 117-137. https://doi.org/10.1108/JFMPC-04-2013-0008

Millward, A. A., \& Sabir, S. (2011). Benefits of a forested urban park: what is the value of Allan Gardens to the city of Toronto, Canada?. Landscape and Urban Planning, 100(3), 177-188. https://doi.org/10.1016/j.landurbplan.2010.11.013

Morancho, A. B. (2003). A hedonic valuation of urban green areas. Landscape and Urban Planning, 66(1), 35-41. https://doi.org/10.1016/S0169-2046(03)00093-8

Nedović-Budić, Z., Tsenkova, S., \& Marcuse, P. (2006). The urban mosaic of post-socialist Europe. In S. Tsenkova \& Z. NedovićBudić (Eds.), The Urban Mosaic of Post-Socialist Europe: Space, Institutions and Policy (pp. 3-20). Heidelberg: Physica-Verlag HD. https://doi.org/10.1007/3-7908-1727-9_1

Panduro, T. E., \& Veie, K. L. (2013). Classification and valuation of urban green spaces - a hedonic house price valuation. Landscape and Urban Planning, 120, 119-128. https://doi.org/10.1016/j.landurbplan.2013.08.009

Robinette, G. O. (1972). Plants, people, and environmental quality. Department of the Interior. National Fark Service.

Rosen, S. (1974). Hedonic prices and implicit markets: product differentiation in pure competition. Journal of Political Economy, 82(1), 34-55. https://doi.org/10.1086/260169

Sadeghian, M. M., \& Vardanyan, Z. (2013). The benefits of urban parks, a review of urban research. Journal of Novel Applied Sciences, 8, 231-237.

Sarkar, C., Webster, C., Pryor, M., Tang, D., Melbourne, S., Zhang, X. and Jianzheng, L. (2015). Exploring associations between urban green, street design and walking: results from the Greater London boroughs. Landscape and Urban Planning, 143, 112-125.

https://doi.org/10.1016/j.landurbplan.2015.06.013 
Stanilov, K., \& Sýkora, L. (2014). Confronting suburbanization: urban decentralization in postsocialist Central and Eastern Europe. Wiley-Blackwell.

Staniszkis, M. (2012). Chasing Warsaw: socio-material dynamics of urban change since 1990. Campus Verlag GmbH.

Streimikiene, D. (2014). Comparative assessment of environmental indicators of quality of life in Romania and Lithuania. Economics \& Sociology, 7(1), 11-21. https://doi.org/10.14254/2071-789X.2014/7-1/2

Szulczewska, B., \& Kaliszuk, E. (2003). Challenges in the planning and management of "Greenstructure" in Warsaw, Poland. Built Environment (1978-), 29(2), 144-156. https://doi.org/10.2148/benv.29.2.144.54464

Tanaś, J., \& Trojanek, M. (2014). Changes in land use structure in suburban zones in Poland after the 90'. Journal of International Studies, 7(3), 81-89. https://doi.org/10.14254/2071-8330.2014/7-3/7

Trojanek, R. (2012). An analysis of changes in dwelling prices in the biggest cities of Poland in 2008-2012 conducted with the application of the hedonic method. Actual Problems of Economics, 7(2), 5-14.

Trojanek, R. (2015). The relation between the attractiveness and value of districts in Warsaw. Montenegrin Journal of Economics, 11(2), 137-145. https://doi.org/10.14254/1800-5845.2015/11-2/9

Trojanek, R. (2016). The impact of green areas on dwelling prices: the case of Poznan city. Entrepreneurial Business and Economics Review, 4(2), 27-35. https://doi.org/10.15678/EBER.2016.040203

Trojanek, R., \& Gluszak, M. (2018). Spatial and time effect of subway on property prices. Journal of Housing and the Built Environment, 33(2), 359-384. https://doi.org/10.1007/s10901-017-9569-y

Trojanek, R., Tanas, J., Raslanas, S., \& Banaitis, A. (2017). The impact of aircraft noise on housing prices in Poznan. Sustainability, 9(11), 2088. https://doi.org/10.3390/su9112088

Troy, A., Grove, J. M., \& Grove, J. M. (2008). Property values, parks, and crime: a hedonic analysis in Baltimore, MD. Landscape and Urban Planning, 87(3), 233-245. https://doi.org/10.1016/j.landurbplan.2008.06.005
Tyrväinen, L., \& Miettinen, A. (2000). Property Prices and urban forest amenities. Journal of Environmental Economics and Management, 39(2), 205-223.

https://doi.org/10.1006/jeem.1999.1097

Votsis, A. (2017). Planning for green infrastructure: the spatial effects of parks, forests, and fields on Helsinki's apartment prices. Ecological Economics, 132, 279-289. https://doi.org/10.1016/j.ecolecon.2016.09.029

Weigher, J. C., \& Zerbst, R. H. (1973). The externalities of neighborhood parks: an empirical investigation. Land Economics, 49(1), 99-105. https://doi.org/10.2307/3145337

Zhang, B., Xie, G., Zhang, C., \& Zhang, J. (2012). The economic benefits of rainwater-runoff reduction by urban green spaces: a case study in Beijing, China. Journal of Environmental Management, 100, 65-71.

https://doi.org/10.1016/j.jenvman.2012.01.015

Zhou, X., \& Parves Rana, M. (2012). Social benefits of urban green space: a conceptual framework of valuation and accessibility measurements Management of Environmental Quality: An International Journal, 23(2), 173-189. https://doi.org/10.1108/14777831211204921

Zietz, J., Zietz, E., \& Sirmans, G. (2008). Determinants of house prices: a quantile regression approach. The Journal of Real Estate Finance and Economics, 37(4), 317-333. https://doi.org/10.1007/s11146-007-9053-7

Zygmunt, R., \& Gluszak, M. (2015). Forest proximity impact on undeveloped land values: a spatial hedonic study. Forest Policy and Economics, 50, 82-89. https://doi.org/10.1016/j.forpol.2014.07.005

Źróbek-Różańska, A., \& Zadworny, D. (2016). Can urban sprawl lead to urban people governing rural areas? Evidence from the Dywity Commune, Poland. Cities, 59, 57-65. https://doi.org/10.1016/j.cities.2016.06.003

Źróbek, S., Trojanek, M., Źróbek-Sokolnik, A., \& Trojanek, R. (2015). The influence of environmental factors on property buyers' choice of residential location in Poland. Journal of International Studies, 8(3), 164-174. 